\title{
A multivariate morphometric analysis of diagnostic traits in southern Italy and Sicily pubescent oaks
}

\author{
Romeo Di Pietro 1 - Antonio Luca Conte $\mathbb{D}$ - \\ Piera Di Marzio (D) - Lorenzo Gianguzzi $($ D \\ Giovanni Spampinato (1D - Orazio Caldarella • \\ Paola Fortini $[$ D
}

Received: 28 December 2019 / Revised: 13 August 2020 / Accepted: 16 September 2020 / Published online: 10 November 2020

(C) The Author(s) 2020

\begin{abstract}
Species identification within the species complex of $Q$. pubescens is a well-known taxonomic challenge among European botanists. Some of the specific pubescent oak binomials currently accepted in various European floras and checklists were originally described in Sicily and southern Calabria. As a consequence, several species belonging to the pubescent oaks group (Q. pubescens, Q. amplifolia, Q. congesta, $Q$. dalechampii, $Q$. leptobalana and $Q$. virgiliana) are reported in the taxonomic and phytosociological literature. To verify whether it was possible to associate a diverse set of morphological characters with each of these different taxa, thirteen natural populations of pubescent oak from Sicily and southern Calabria were sampled. A total of 391 trees, 3,887 leaves and 1,047
\end{abstract}

Supplementary Information The online version of this article (https://doi.org/10.1007/s12224-020-09378-0) contains supplementary material, which is available to authorized users.

R. Di Pietro $(\bowtie)$

Department PDTA, University of Rome Sapienza, 00196 Rome, Italy

e-mail: romeo.dipietro@uniroma1.it

A. L. Conte · P. Di Marzio · P. Fortini

Department of Bioscience and Territory, University of Molise, 86090 Pesche (IS), Italy

\section{Gianguzzi $\cdot$ O. Caldarella}

Department of Scienze Agrarie e Forestali, University of Palermo, Palermo, Italy

\section{G. Spampinato}

Department of AGRARIA, Mediterranean University of Reggio Calabria, Reggio Calabria, Italy fruits were collected. Overall, 28 morphological characters of oak leaves and fruits were statistically analysed using univariate and multivariate procedures. The results showed that neither the groups of morphological diversity identified by cluster analysis, nor those obtained by our expert identification through the use of analytical keys, matched with the current taxonomical frameworks as proposed by the most recent floras and checklists. Nearly all of the morphological characters considered displayed a more or less continuous trend of variation, both within and among populations. In the light of these findings it seems unlikely that more than one biological species of pubescent oak occurs in Sicily and southern Calabria.

Keywords Diagnostic morphological characters . Nomenclature · Quercus · Southern Europe · Taxonomy

\section{Introduction}

The majority of Southern European forest communities are characterized by the dominance of species belonging to the genus Quercus L. The genus includes about 435 species throughout the world, but this figure is probably an underestimate (Denk et al. 2017). In Europe, there are about 34 species which are distributed across the whole continent. The most recent classifications based on molecular studies (Manos et al. 2008; Denk and Grimm 2010; Hubert et al. 2014; Denk et al. 2017; Hipp et al. 2019) have supported the hypothesis that the genus Quercus is divided into two monophyletic groups, 
which correspond to two different subgenera: subgen. Cerris and subgen. Quercus, the latter composed of five sections. The European white oaks belong to the section Quercus and originated from two waves of Palaeogene radiation from north America across both the northAtlantic land bridge and the Bering land bridge (Denk et al. 2017).

The total number of oak species occurring in Italy is not known exactly, because the classification has been subject to continuous change over time. It ranges between nine and fifteen, depending on flora or checklist. This discrepancy concerning the number of accepted oak species names is caused, almost exclusively, by the descriptive and interpretative nebulosity that still characterizes the species complex of $Q$. pubescens (Table 1).

The classification of oaks is based on a variable number of morphological traits of leaves and acorns, such as the degree of pubescence, its persistence on twigs and leaves, the dimensional traits of the leaf, the numbers, shapes and depths of the leaf lobes, length of the petiole, type of the margin and the surface of the cupule, among others. However, while the classification system enables reasonably clear separation among wellknown white oak species (e.g. Q. faginea, Q. frainetto, $Q$. pyrenaica, $Q$. robur) within particularly critical groups (the species complexes of $Q$. petraea and especially that of $Q$. pubescens), taxonomists are facing considerable difficulties caused by more or less continuous patterns of morphological variation (see Bakis and Babaç 2014). This phenomenon, more prominent in the oaks than in other genera of European trees, is generally ascribed to a complex pattern of introgression and hybridization and to convergent morphological evolutionary processes in oaks (Oh and Manos 2008; Kremer et al. 2012; Denk et al. 2017). Such hybridization events occurred mostly in geographical areas such as southern Italy, where the thermophilous woody flora took refuge during cold periods of the Quaternary (Follieri et al. 1989; Petit et al. 2006; Magri et al. 2007; Leroy et al. 2019b).

Even if we exclude all binomials described from southern Italy and Sicily, which are now generally considered synonyms for other oak names, such as Quercus apennina Lam., Q. cupaniana Guss., Q. minae Lojac., Q. sicula Borzi ex Lojac., Q. tenoreana Borzì (cf. Gussone 1844; Borzì 1905, 1911; Lojacono-Pojero 1907, 1913-15), a high number of pubescent oak species is still reported in the most recent floras and checklists. According to Brullo et al. (1999a) and Pignatti et al. (2017-2019) the Euro-Mediterranean/ SE-European Q. pubescens Willd. is absent from southern Italy where it is replaced by other deciduous thermophilous oak species with a steno-Mediterranean or Euro-Mediterranean distribution, for example, Q. congesta C. Pres1., Q. dalechampii Ten. Q. virgiliana (Ten.) Ten., or southern Italian endemic distribution, for example $Q$. leptobalana Guss. and Q. amplifolia Guss. However, these taxa are not treated in the same manner by oak taxonomists in the rest of Europe. In fact, $Q$. pubescens is considered as a valid binomial throughout Europe, except for Spain, where it is, for nomenclatural reasons, substituted by the name $Q$. humilis Mill., of which the name $Q$. pubescens is considered a later synonym (Amaral Franco 1990). Concerning the other taxa, some of these are accepted in many European floras and checklists (e.g. $Q$. congesta and $Q$. dalechampii), while others (e.g. Q. virgiliana) are reported in some SoutheasternEuropean floras, and Q. amplifolia and Q. leptobalana are considered endemic to southern Italy.

In addition to the lack of agreement on the number of white oak species, there are persistent cases of 'misinterpretation' that destabilize the Italian and European deciduous oak classification system. A typical example is $Q$. dalechampii, which although unequivocally typified and definitively assigned to the pubescent oaks group (Di Pietro et al. 2012), is in some cases still classified as belonging to the Q. petraea species complex. This is evident when looking at distribution maps that mix together records of pubescent and glabrous specimens under the name $Q$. dalechampii (see Euro+ Med 2006-2014).

Several papers aiming to establish the possible occurrence of other pubescent oak species in addition to Q. pubescens Willd. have been published in the last decade for Southern Europe. Some of them were primarily based on the analysis of morphological characters, but also involved geometric morphometric analyses (Viscosi and Fortini 2011), micro-morphological leaf traits (Scareli-Santos et al. 2007; Fortini et al. 2009; Panahi et al. 2012; Scareli-Santos et al. 2013), fractal analysis of leaf morphology (Musarella et al. 2018), and molecular data (Curtu et al. 2007a, b, 2015). As far as southern Italy is concerned, two recent papers (Di Pietro et al. 2016, 2020) analysed 24 south-eastern Italian populations of pubescent oaks from a macromorphological and molecular standpoint. 


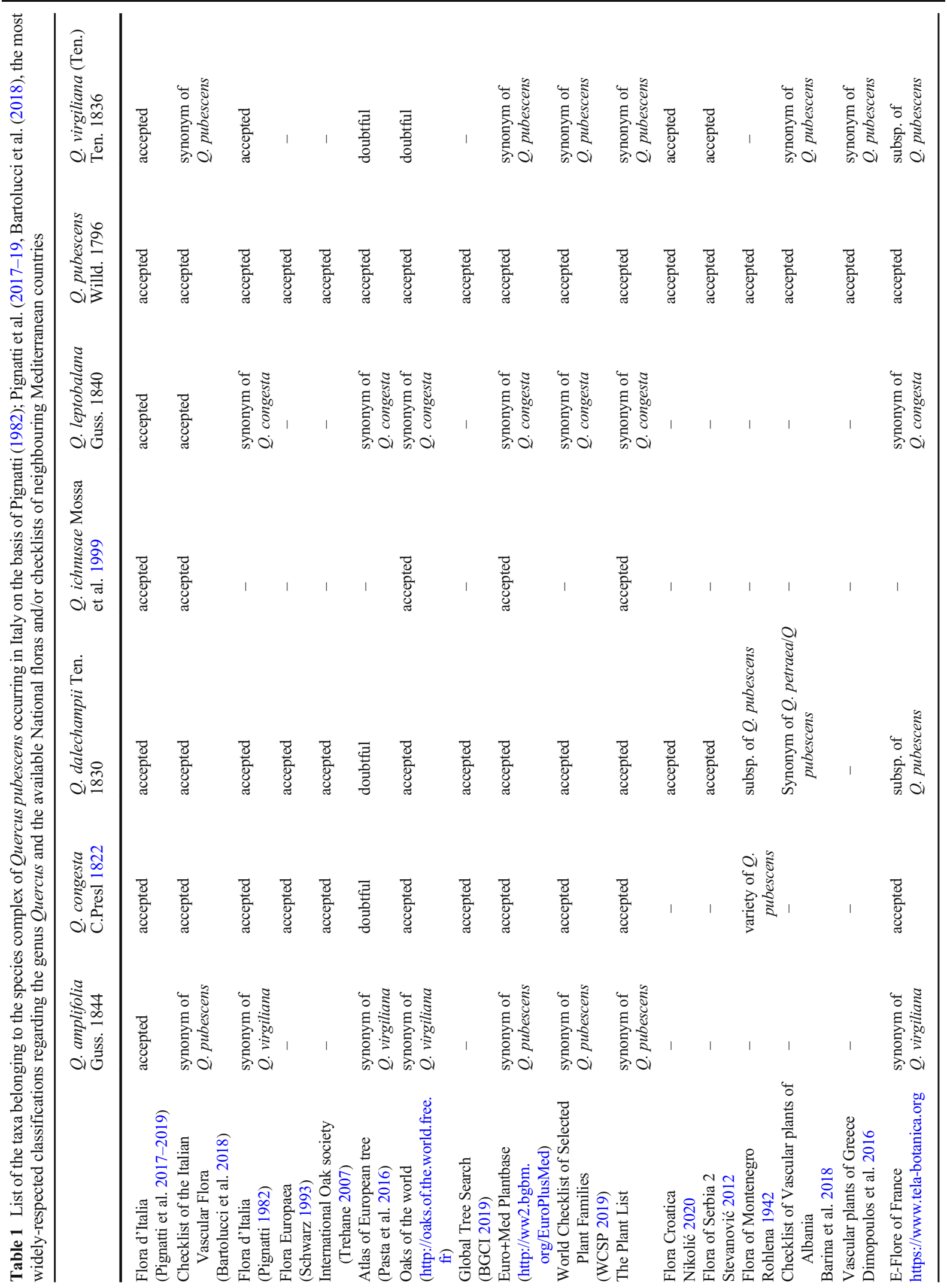


In the present study, we analysed the pubescent oak populations of Sicily and southern Calabria, which are crucial areas for the diversity of deciduous Mediterranean oaks. Sicily and southern Calabria host the highest number of pubescent oak species currently reported for the Italian Peninsula (Pignatti et al. 2017-2019; Bartolucci et al. 2018), the majority of their loci classici (Brundu et al. 2017; Peruzzi et al. 2019) and the highest number of pubescent oak forest phytosociological associations (Blasi et al. 2004). Furthermore, southern Italy provided refuge areas, both primary and secondary, during glacial periods which constitute an important reservoir of genetic diversity that has been preserved over time despite the strong anthropogenic pressure over the last three millennia (Médail and Diadema 2009). It should be noted that the reference to phytosociology is relevant to the taxonomic treatment if we consider that according to some authors (e.g. Guarino et al. 2015) the high coenological and floristic diversity found in the pubescent oak associations of southern Italy can be fully explained only by admitting the occurrence of 'a blend of different species, partially blurred by systematic hybridization and introgression' (ibid.).

The aim of this paper is to verify whether this high diversity, which involves several pubescent oak taxa, is supported by (i) the results of multivariate statistical analyses and (ii) sets of unambiguous and identifiable diagnostic morphometric characters.

\section{Material and methods}

Sampling

Thirteen pubescent oak populations were sampled throughout Sicily and southern Calabria. According to the floristic and phytosociological literature, these populations included the following taxa: Q. amplifolia, Q. congesta, Q. dalechampii, $Q$. leptobalana and $Q$. virgiliana. The collection sites were selected from the entire deciduous oak woodland bioclimatic belt, from sea level to the lower montane belt (Gianguzzi et al. 2016), and different types of geological substrates (Fig. 1 and Table 2). Where possible, priority was given to collection from populations located near to the loci classici of the species in question and to those already described from a syntaxonomic point of view in published phytosociological tables
(Table 3). Leaves and fruits were collected from 27 to 33 adult trees per site in autumn 2017 and 2018. Up to three branches were selected randomly in the middle-upper part of the crown. Voucher specimens are stored in the Herbarium of the University of Molise (IS).

Ten leaves per tree specimen were pressed dried and scanned using an Epson GT-15000 scanner with a resolution of $600 \mathrm{dpi}$, with the abaxial surface facing upwards, and measured with ImageJ (Rasband 19972007).

In total, seventeen morphological characters were assessed (Table 3 and Online Resource 1): Seven primary characters (leaf area, leaf perimeter, leaf lamina length, petiole length, width of the major lobe, sinus width, widest point) were measured as described in Fortini et al. (2015). Five characters were derived characters (leaf compactness, obversity, lamina/petiole ratio, lobe depth ratio, lobe width ratio). One character (number of lobes on the left side) was numerical (counted), and one other (scoring of the basal shape of the lamina) was evaluated following Kremer et al. (2002). Finally, three characters (abaxial and adaxial laminar pubescence and twig pubescence) were observed on voucher specimens following Kissling (1980).

Three fruits (acorns) per tree specimen were measured using a digital electronic calliper MAURER 93110. In total, eleven fruit characters were assessed from voucher specimens (Table 4 and Online Resource 1), including four dimensional characters (cupule length, cupule width, acorn length, acorn width), two derived characters (cupule width/cupule length and cupule length/acorn length) and five categorical (dimensionless) characters: regularity of cupule edge, scale shape, gibbosity (tuberculate bases of cupule scales), cupule internal hairiness and type of exterior of cupule edge.

In total, 3,887 leaves and 1,047 fruits were collected from 391 tree specimens. Since not all sampled tree specimens bore fruit, the final and complete matrix subjected to statistical analysis was composed of 333 specimens.

Because the dichotomous keys of Flora D'Italia (Pignatti et al. 2017-2019) takes into consideration the appearance of the bark ribs, this character was also observed for all the sampled oak specimens to aid identification (see Online Resource 2). 


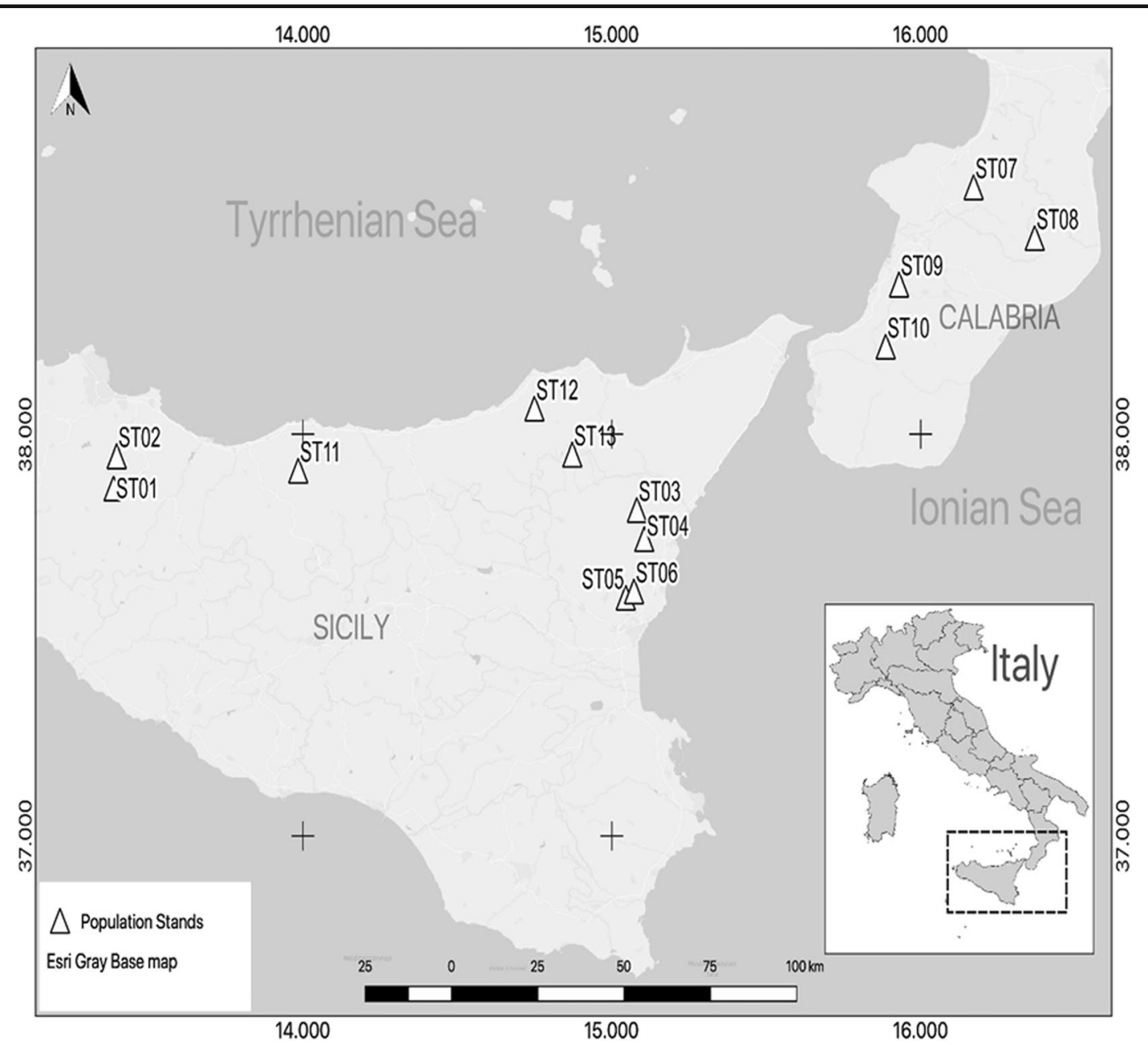

Fig. 1 Spatial distribution of the thirteen pubescent oak populations sampled in the study area.

Data analysis

Partition of the total variance of leaf morphology was evaluated through the two-levels nested analysis of variance (nested ANOVA) which gave rise to results readable at different hierarchical level: (a) inter-population (variance among different populations), (b) intrapopulation (variance among the trees of a single population) and (c) individual (variance among the leaves of a single tree). A spreadsheet suitable for this purpose (McDonald 2009) was modified to analyse more than fifty subgroups, with up to 200 observations per subgroup, and used subsequently to perform the nested ANOVA (with Satterthwaite approximation, because of the unequal sample sizes of the subgroups) on the entire data set of 3,887 leaves and fourteen leaf variables.
The matrix of 333 tree specimens and 28 leaf and fruit variables was analysed. To identify possible diversity groups, an exploratory analysis was performed on standardized data through Hierarchical clustering with PAST v. 4.03 using Euclidean distance, Ward's minimum variance method (Hammer et al. 2001); Hierarchical clustering with JASP v. 0.13 (estimation method 'moment', model optimized with respect to the silhouette value (Jasp Team 2020).); fuzzy k-means clustering with XLSTAT vers. 2020.3.1 (coefficient of fuzziness = 1.1, method: cosine, 20 repetitions, not weighted, initialization method: $\mathrm{K} \|$ ); k-means clustering with JASP vers. 0.13 (estimation method 'moment', model optimized with respect to the silhouette value).

A principal component analysis (PCA) was performed with PAST and the results showed with the 





superimposition of the groups highlighted by the cluster analyses.

Furthermore, using XLSTAT 2020.1.1 (ADDINSOFT 2020), the consistency of the groups identified by the four cluster analyses was tested with the Kruskal-Wallis test $(P$ calculated with the Montecarlo method, 1000 resamplings) and then by the multiple pairwise comparisons (Dunn's procedures with Bonferroni correction).

Finally, a linear discriminant classification (LDC, estimation method 'moment') using JASP was performed.

To confirm the result of the a-priori classification based on the guide species of the oak communities investigated, an expert classification of all the tree specimens collected was also performed based on the analytical key for oak identification published in the new edition of Flora d'Italia (Pignatti et al. 2017-2019). In some cases of particularly critical specimens, it was necessary to do some forcing to complete the identification process. When the incompatibility among diagnostic characters turned out to be too pronounced and would have required an excessive degree of subjectivity to complete the identification process, the specimen was classified as 'preliminarily indeterminate'. When we found a lower degree of incompatibility among diagnostic characters, we decided to choose one of the two options proposed by the identification key arbitrarily. Specimens identified in this way were subsequently classified adding the epithet 'doubtful' (e.g. Q. virgiliana doubtful, $Q$. congesta doubtful, etc.).

Our expert identifications of the specimens were compared with what was expected for the sampling sites based on the phytosociological tables of the associations already published for those areas or for strictly neighbouring areas. All the pubescent oaks occurring at each collection site were collected by randomized sampling and not selectively directed toward the collection of one or other putative species. In this context, the expected values of the various oak species were obtained by making a correlation between the number of specimens we collected and the values of frequency and coverage of the oak species reported in the phytosociological tables of the pubescent oak forest associations published for those areas.

\section{Results}

The nested ANOVA showed that the morphological character variability observed among the leaves of an individual tree (ranging between $42.40 \%$ and $89.73 \%$ ) accounted for the highest portion of the total variability. This was followed by the variability observed among the leaves of the tree specimens belonging to the same population $(9.37 \%-46.73 \%)$ and by that observed among the leaves of the specimens belonging to different populations $(0.83 \%-17.72 \%$; Online Resource 3$)$.

The hierarchical cluster analysis of the matrix based on leaf and fruit characters produced a dendrogram showing two main groups of oak specimens (Online Resource 4a). The occurrence of two groups was also revealed by the other three cluster analyses performed (Online Resource 4b-e).

By making a pairwise comparison between the different partitions obtained by the cluster analyses on the basis of the presence of the tree specimens in the two groups and regardless of the order of the groups, an agreement always higher than $80 \%$, was found (Online Resource 4f,g).

The relatively low degree of dissimilarity between the two main groups identified by the cluster analysis may be observed in the PCA diagram with partition superimposed (Fig. 2). The two clusters exhibited a significant overlap when considering the grouping based on the hierarchical classifications whereas the superimposion of k-means and the fuzzy k-means clustering showed a clearer separation along PCA axis I (20.03\% of the variance) (Online Resource 4h). The variables correlated to the first PCA axis are those pertaining to leaf dimensions (Area, Per, LL, LW, WP), while the variables correlated to the second PCA axis are those concerning the dimensions of the fruit (CW, AL, AW). Summary tables from Kruskall-Wallis test $(\alpha=0.05)$ showed that the separation of the two clusters was clearer using the fuzzy k-means and the kmeans clustering (Online Resource 4i) for which the only insignificant variables were $\mathrm{Ob}, \mathrm{LWR}, \mathrm{CL}, \mathrm{RCE}$, TCE and Co, LWR, CL, RCE, TCE, respectively. The linear discriminant classification LDC attributed to the fuzzy k-means clustering the best value of the accuracy test (Online Resource 41-m) and for this reason we decided to accept the two groups identified by fuzzy kmeans clustering for further analysis and discussion.

Eleven populations out of the thirteen investigated contained specimens occurring in the both main two 
Table 3 Description of leaf morphological characters

\begin{tabular}{|c|c|c|}
\hline Variable & Code & Variable description \\
\hline Area & Area & Leaf area $\left[\mathrm{cm}^{2}\right]$ \\
\hline Perimeter & Per & Leaf perimeter $[\mathrm{cm}]$ \\
\hline Petiole length & PL & Leaf petiole length from the base of the lamina to the base of the petiole $[\mathrm{cm}]$ \\
\hline Lamina length & LL & Leaf lamina length incl. Lobes and sinuses $[\mathrm{cm}]$ \\
\hline Lobe width & LW & $\begin{array}{l}\text { Width of the major lobe, from the apex of the lobe to } \\
\text { the central axis coinciding with the main vein of the leaf }[\mathrm{cm}]\end{array}$ \\
\hline Sinus width & SW & $\begin{array}{l}\text { Distance between the maximum point of curvature of the sinus } \\
\text { immediately below the main lobe and the central axis coinciding } \\
\text { with the main vein of the leaf }[\mathrm{cm}]\end{array}$ \\
\hline Widest point & WP & Distance between the apex of the major lobe and the base of the lamina [cm] \\
\hline Number of lobes & NL & $\begin{array}{l}\text { Number of lobes on the left side of the leaf lamina, excluding the terminal } \\
\text { central apex of the leaf lamina }\end{array}$ \\
\hline Basal shape of the lamina & BSL & $\begin{array}{l}\text { Basal shape of the lamina assessed on the left side on a scale varying from } \\
1 \text { to } 9 \text { (Kremer et al. 2002) }\end{array}$ \\
\hline Compactness & Co & $\operatorname{sqrt}((4 / \mathrm{pi}) * \operatorname{area}) / \mathrm{LL}$ \\
\hline Obversity & $\mathrm{Ob}$ & WP/LL*100 (Kremer et al. 2002) \\
\hline Petiole ratio & PR & $\mathrm{PL} /(\mathrm{LL}+\mathrm{PL}) * 100$ (Kremer et al. 2002) \\
\hline Lobe depth ratio & LDR & (LW-SW)/LW*100 (Kremer et al. 2002) \\
\hline Lobe width ratio & LWR & LW/LL*100 (Kremer et al. 2002) \\
\hline $\begin{array}{l}\text { Abaxial laminar pubescence } \\
\text { Adaxial laminar pubescence }\end{array}$ & $\begin{array}{l}\text { AB-PU } \\
\text { AD-PU }\end{array}$ & $\begin{array}{l}\text { Assessed on voucher specimens using a scale varying } \\
\text { from } 0 \text { to } 6 \text { (Kissling 1980) }\end{array}$ \\
\hline Twig pubescence & TW-PU & \\
\hline
\end{tabular}

clusters identified by the fuzzy k-means clustering (Fig. 3). Populations ST11 and ST13 were the only populations where all specimens belonged to the same main clusters (Group 1). In four populations (ST01, ST04, ST07 and ST09), one of the clusters (Group 2) was dominant, comprising more than $70 \%$ of the specimens. All the other oak populations investigated were mixed with less than $70 \%$ of the specimens in one or the other main cluster.

From the box-plot diagrams, produced from the Kruskall-Wallis test $(\alpha=0.05)$, and the multiple pairwise comparisons using Dunn's procedure, it was found that the separation of the two main clusters of the fuzzy k-means clustering was mostly related to leaf dimensions (Area, LL, LW, Per, PL, SW and WP), lobe depth ratio (LDR), petiole ratio (PR), number of lobes (NL), basal shape of the lamina (BSL), compactness (Co), and leaf pubescence (AB-PU, AD-PU and TW$\mathrm{PU})$. Among fruit characters, cupule width (CW), acorn length and width (AL and AW), cupule form (CW/CL), cupule internal hairiness $(\mathrm{CIH})$, and cupule length/acorn length ratio (CL/AL), scale shape (SS), tuberculate bases of the cup scales $(\mathrm{G})$, and cupule internal hairiness
(CIH) differentiate slightly between the two groups (Online Resource 5).

The expert identification of the 333 samples, achieved through rigorous use of the analytical keys of the most recent edition of Flora d'Italia (Pignatti et al. 2017-2019), proved tortuous. In fact, we found impossible to assign thirty individual trees out of the 333 sampled whereas 86 specimens were classified as doubtful.

The labelling of the dendrogram with the names derived from our expert identification did not show the separation into groups containing specimens belonging to the same putative species (Online Resource 4a). Also in the PCA there is a marked dispersion of the specimens belonging to the same putative species (Fig. 2a).

The comparison of the number of specimens identified and the number of specimens expected on the basis of the published phytosociological papers (Table 5) showed that for $Q$. congesta (36 specimens identified with certainty and 85 with doubtful specimens included) and $Q$. dalechampii $(87 / 101)$ the number of specimens identified (when the doubtful specimens are included) more or less 
Table 4 Description of fruit morphological characters

\begin{tabular}{|c|c|c|}
\hline Variable & Code & Variable description \\
\hline Cupule length & $\mathrm{CL}$ & Cupule length $[\mathrm{mm}]$ \\
\hline Cupule width & $\mathrm{CW}$ & Cupule width $[\mathrm{mm}]$ \\
\hline Acorn length & $\mathrm{AL}$ & Acorn length $[\mathrm{mm}]$ \\
\hline Acorn width & AW & Acorn width $[\mathrm{mm}]$ \\
\hline Cupule form & $\mathrm{CW} / \mathrm{CL}$ & Ratio between cupule width and length \\
\hline Cupule cover & $\mathrm{CL} / \mathrm{AL}$ & Ratio between cupule and acorn length \\
\hline Regularity of cupule edge & RCE & 1 - curved edge; 2 - regular edge; 3 - irregular edge \\
\hline Scale shape & SS & 1 - triangular; 2 - pyriform \\
\hline Tuberculate bases of the cup scales & G & 1 - present; 2 - absent \\
\hline Cupule internal hairness & $\mathrm{CIH}$ & 1 - absent; 2 - poor; 3 -medium; 4 - abundant \\
\hline Type of exterior of cupule edge & TCE & $\begin{array}{l}1 \text { - scales not exceeding the cupule edge; } 2 \text { - scales } \\
\text { slightly exceeding the cupule edge; } 3 \text { - scales } \\
\text { markedly exceeding the cupule edge }\end{array}$ \\
\hline
\end{tabular}

correspond to what was expected (64 and 93 specimens, respectively). More than half of the doubtful specimens in the whole dataset belong to Q. congesta, which is the only taxon that showed a higher number of doubtful specimens than identified specimens. However, more than half (21/36) of the specimens identified with certainty as $Q$. congesta came from sites where this species was not expected while this ratio was significantly lower for $Q$. dalechampii (21/87). Two out of the three collection sites where unexpected Q. dalechampii specimens were found (ST6 and ST2, both referring to the association OleoQuercetum virgilianae), showed $Q$. dalechampii as the most abundant species. Only twelve specimens were identified with certainty as Q. virgiliana (14 including doubtful specimens) whereas the number expected was 110 . The number of specimens identified with certainty as Q. leptobalana was 39 (56 including doubtful specimens). Only fourteen specimens out of the 39 Q. leptobalana specimens identified were collected in the two sites reported as Quercetum leptobalanae (4 specimens in ST1 and 10 in ST11), while the remaining specimens came from other collection sites in Sicily and southern Calabria at which no $Q$. leptobalana was expected. No specimens were identified as $Q$. amplifolia, despite 38 specimens being expected, whereas we identified 35 specimens of $Q$. pubescens and seven specimens of $Q$. ichnusae, although these two taxa are currently not reported from the study area (cf. Brullo et al. 1999a, b; Pignatti et al. 2017-2019).

\section{Discussion}

Over recent years a major international effort has been made to revise the entire Quercus genus, which, worldwide, had reached the number of 500-650 species (Govaerts and Frodin 1998). In the taxonomical framework of Southern Europe the Q. pubescens species complex remains an unresolved tangle. Papers published in Southern Europe in the last fifteen years regarding the morphological variability of the European white oaks have been moving in more or less the same direction: that a critical evaluation of the many oak taxa is needed regardless of whether they were included in the national floras or checklists as accepted species or not (Franjic et al. 2006; Enescu et al. 2013; Wellstein and Spada 2015; Di Pietro et al. 2016, 2020).

\section{The concept of species in Quercus}

Does it still make sense to classify oak populations to different species when it has been known for at least forty years that the genus Quercus is subject to interspecific hybridization? Actually, a definitive answer to this question has never been provided and is well beyond the scope of this paper. We incline to think that the answer is yes. The topic is still widely debated and a "measured scepticism about oak species is not uncommon among 

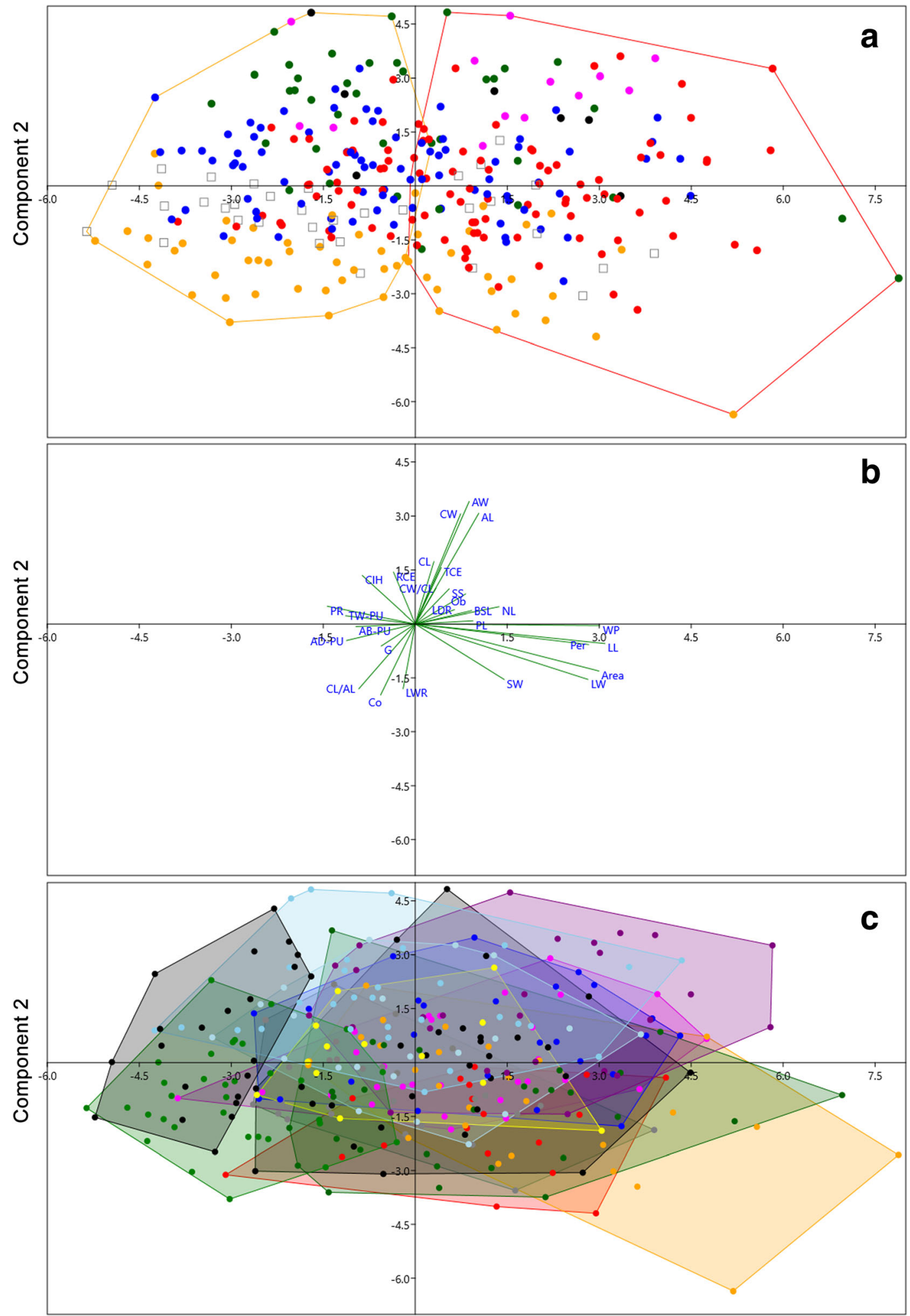

Component 1 
Fig. 2 Principal component analysis (PCA) based on the 28 morphological traits. The first axis explains $20.028 \%$ of the total variance, while the second explains $12.114 \%$. a - The two groups obtained by the fuzzy k-means clustering are emphasized by the convex hulls (Group 1 on the left and Group 2 on the right). The oak taxa listed comprise both specimens that were positively identified and specimens which remained indeterminate (dots Quercus dalechampii, Q. congesta, Q. ichnusae, Q. leptobalana, $Q$. pubescens, $Q$. virgiliana; Squares - doubtful specimens). b Projection of the original axes (variables). c - The thirteen populations sampled emphasized by convex hulls: ST01 (red), ST02 (fuchsia), ST03 (grey), ST04 (orange), ST05 (dark green), ST06 (black), ST07 (blue), ST08 (yellow), ST09 (purple), ST10 (light blue), ST11 (green), ST12 (sky blue), ST13 (dark golden).

botanists even today' (Hipp 2015). Already in the first half of the 1970s some authors (e.g. Van Valen 1976; Burger 1975; Hardin 1975) had argued that if gene flow among different oak species might exceed gene flow between populations of a single species, then the concept of species in oaks needed to be significantly rearranged. Accordingly, these authors proposed that oak species should be considered as ecologicaltaxonomic entities rather than reproductively defined ones. More recently, the availability of increasingly refined molecular markers has led to this issue being reconsidered from a different perspective. Certainly, hybridization may have been one of the factors underlying the palaeogenic radiation of oaks and their postglacial spread northwards. Indeed, recent population genomic studies have defined hybridization as a microevolutionary process able to reinforce adaptation and enhance migration, thus improving the ability of individuals to colonize new habitats (Cavender-Bares 2019; Leroy et al. 2019a, b; Kremer and Hipp 2019). However, most researchers in the field argue that hybridization does not lead to the fragmentation of the integrity of species if even a small part of the genome is able to maintain species barriers (Eaton et al. 2015). Particular genes (e.g. those under selection for drought-tolerance or photoperiodic control of growth) were found to be highly contributing to the maintenance of genetic divergence between ecologically distinct species, suggesting that selection manages to cope with gene-flow (LindRiehl et al. 2014; Oney-Birol et al. 2018). Much of the variation in oaks that has been interpreted as evidence of hybridization in the past can more properly be considered as morphological variation within highly variable species attributable to intraspecific phenotypic plasticity (i.e. the ability of a species to produce different phenotypes with varying environmental conditions). Furthermore, it has been demonstrated that 'gene flow among species is normally overwhelmed by gene flow within species' (Gerber et al. 2014). These and other arguments led Hipp et al. (2015) 'to say confidently against the backdrop of the last 20 years of oak research, that oak species are real'.

Several recent works using genome-scale data have been successful in resolving relationships throughout the Quercus phylogenetic tree, from the definition of the two major clades worldwide (Denk et al. 2017; Hipp et al. 2015, 2018, 2019; Crowl et al. 2019), up to the fine-scale infrasectional level (Olalde et al. 2002). However, as underlined in Denk et al. (2017), the major challenge for future studies is to establish the molecular and morphological circumscription at species rank and their biogeographic and ecological characterization. In the last two decades important results have been achieved in identifying the occurrence (or the absence) of species boundaries between taxonomically critical groups of sympatric Southern-European white oaks using molecular markers (Bruschi et al. 2000; Jedináková-Schmidtová et al. 2004; Franjic et al. 2006; Fortini et al. 2009; Curtu et al. 2011; Enescu et al. 2013; Crăciunescu et al. 2015; Di Pietro et al. 2020). In our opinion, the necessary further step should be to link discontinuities highlighted at the genomic level to a well-defined and unambiguous set of diagnostic morphological, ecological and coenological characters to circumscribe oak species. Also, proper species names should be found, carefully applying the rules of the International Code of Nomenclature (Turland et al. 2018). As a consequence, a name linked to a type specimen is also linked to a certain geographical location (locus classicus) and possibly (but with a significantly lower degree of certainty) to a larger geographical area. Unfortunately, correspondence between provenance and nomenclatural identity of the collected material tends sometimes to be disregarded, leading inevitably to mistaken or deviated conclusions. This paper, even though restricted to a relatively small geographical area, represents an essential step in this direction.

The current state of the art

What has emerged from the most recent taxonomic investigations of European white oaks on the basis of morphological characters (micro- and macro-) is that the current 'state of art' of identification of pubescent oak 


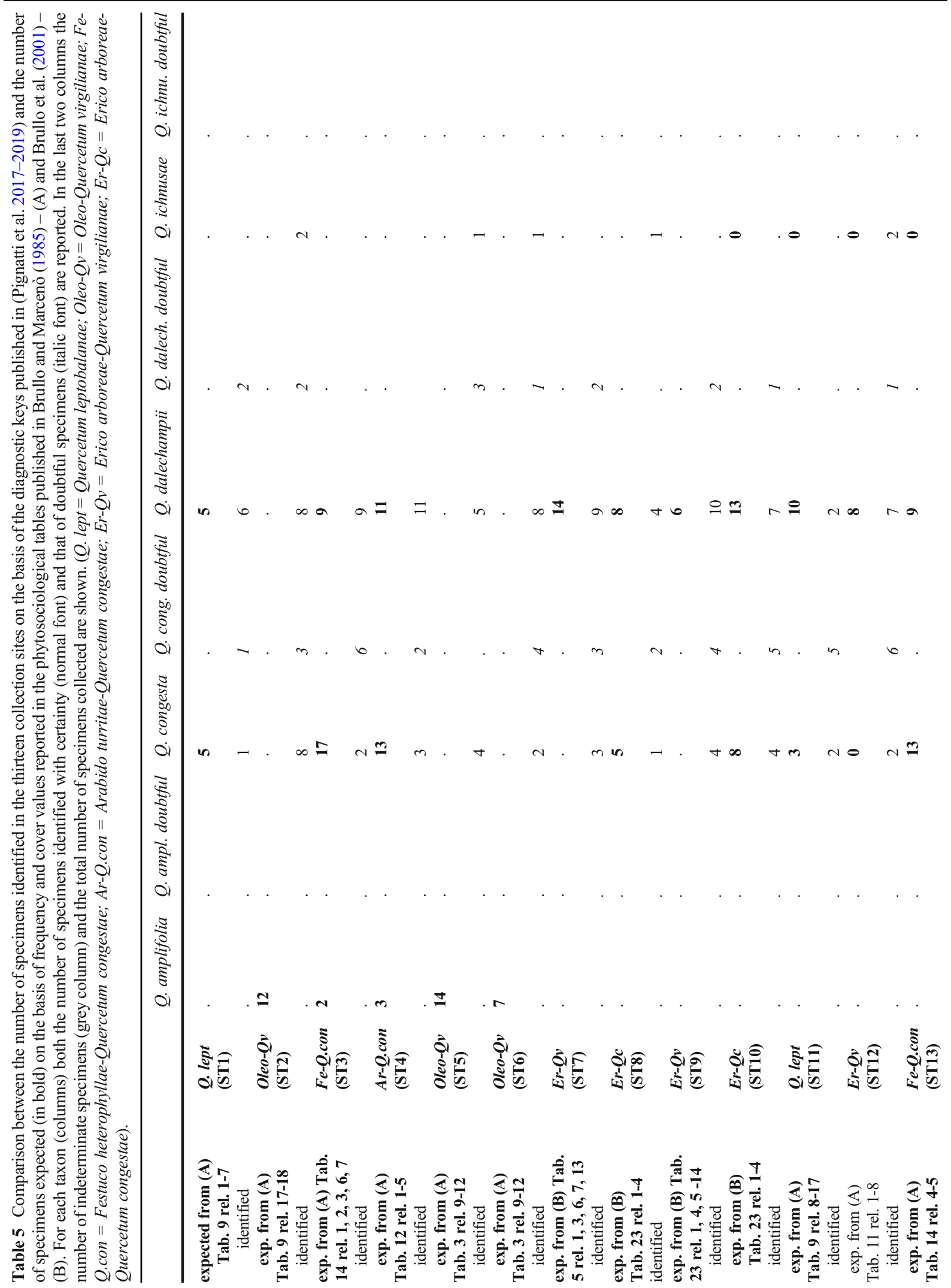




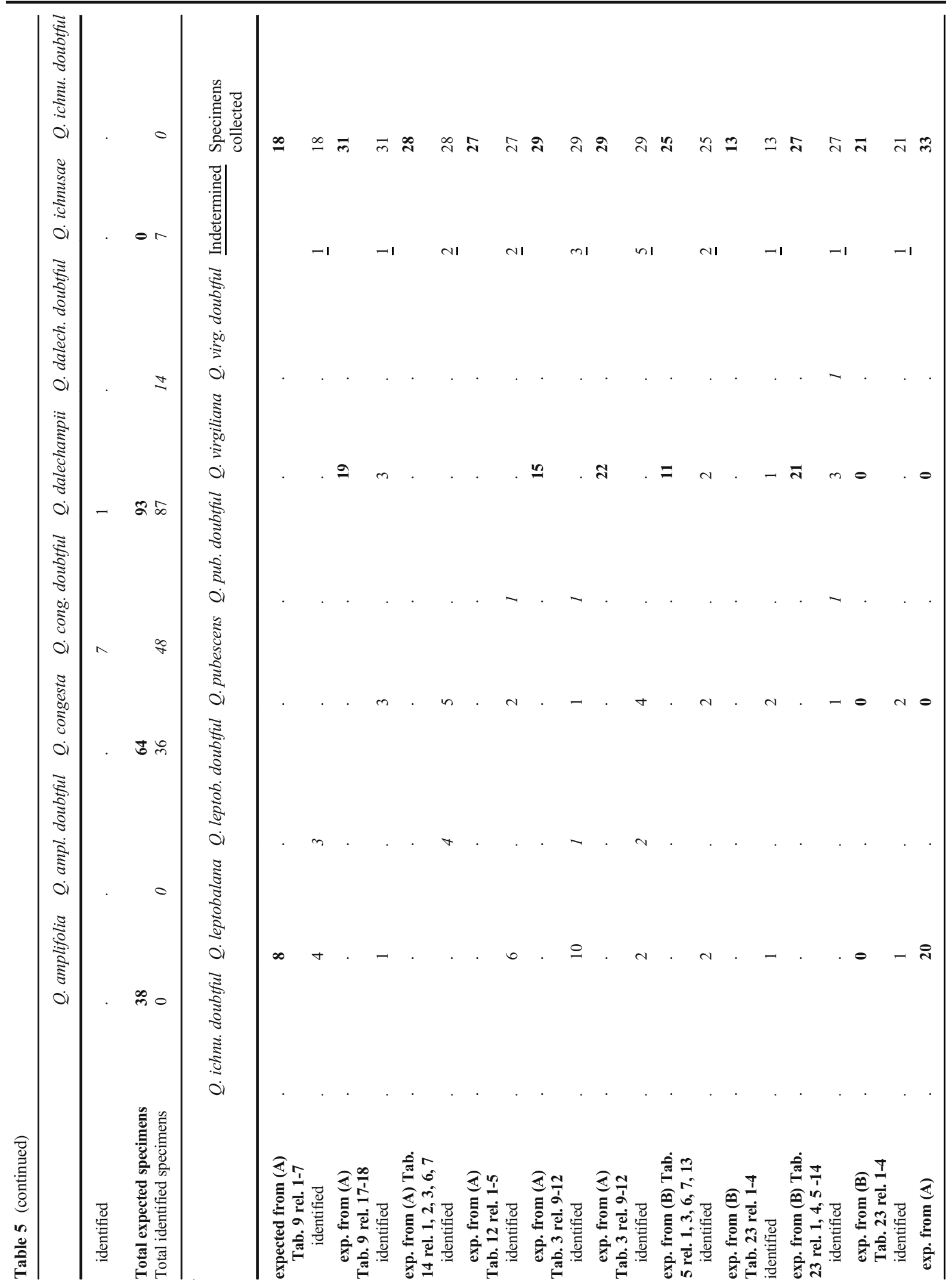




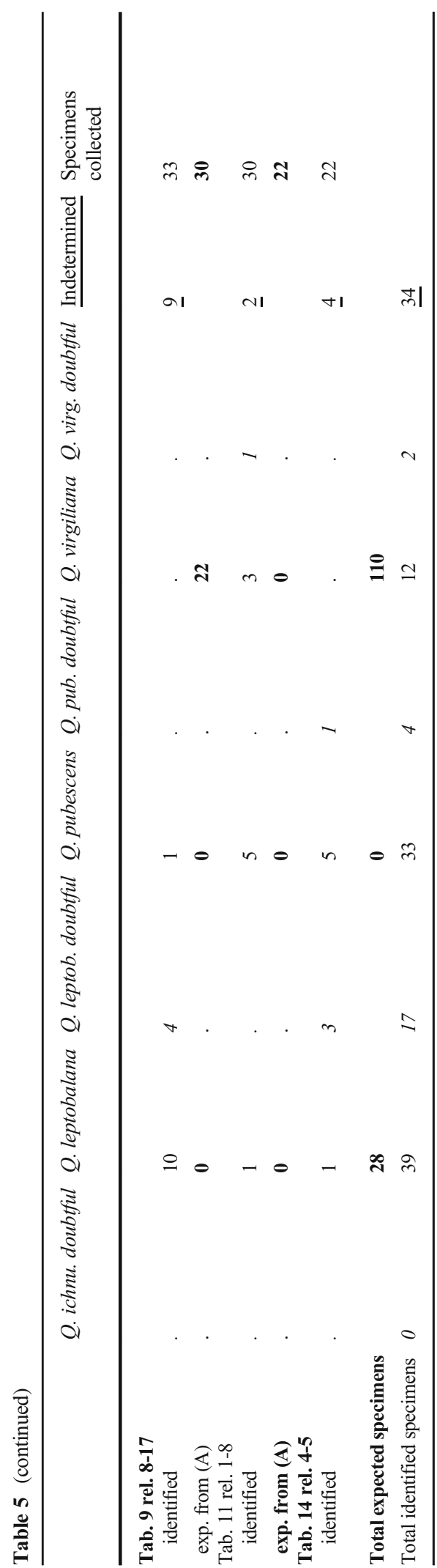

specimens does not allow unequivocal identification at the species rank. Once one arrives at the objective dichotomy separating 'pubescent-twig oaks' (Q. pubescens species complex) and 'glabrous-twig oaks' (Q. petraea species complex), the subsequent steps in taxonomic discrimination become markedly subjective (for both groups) and therefore not universally shared. As regards Italy, we are fairly sure about the identification of the four main species of white oaks, namely $Q$. frainetto, $Q$. petraea, $Q$. robur and Q. pubescens. As regards the first three of these taxa, there have never been serious doubts that they had to be accepted as valid species and only a few others considered morphological variations within them to deserve the rank of variety or, at most, subspecies (see Q. petraea subsp. austrotyrrhena Brullo, Guarino and Siracusa or Q. robur subsp. brutia (Ten.) O. Schwarz). Only in the Quercus petraea group there is no general agreement on the validity of some taxa (e.g. Q. petraea subsp. polycarpa and $Q$. petraea subsp. iberica) and on the choice of the name to refer to what was previously called Q. dalechampii (cf. Bock and Tison 2013, Di Pietro et al. 2012; Raab-Straube and Raus 2013; Kučera 2018). This is in no way comparable, however, with the taxonomic and nomenclatural chaos in which the group of $Q$. pubescens is immersed. Indeed, the well-known morphological variability of this group has often been used to advance proposals to split it in a multitude of narrowly defined taxa. The majority of these 'narrow endemic eco-morphotypes' (see Pasta et al. 2016) are generally considered synonyms of $Q$. pubescens. In some rare cases the opposite path occurs, that is, populations attributed preliminarily to $Q$. pubescens that have subsequently acquired taxonomic autonomy. An example may be $Q$. kotschyana O. Schwarz, an endemic species of Lebanon previously included in $Q$. pubescens as $Q$. pubescens subsp. pinnatifida Gmelin (Stephan and Teeny 2017; Hipp et al. 2019) or considered an hybrid between $Q$. pubescens and Q. cerris under the name Quercus $\times$ baenitzii (see Camus 1936-54 and http://oaks.of.the.world.free. fr/quercus_baenitzii.htm), or $Q$. pubescens subsp. crispata (already accepted in Schwarz 1993).

Among the Southern European countries, Italy is certainly the one where the splitter tendency is more deeply rooted. Accordingly, several Italian authors keep on referring several pubescent oak taxa other than Q. pubescens in their floristic, taxonomic and phytosociological contributions (cf. Brullo and Marcenò 1985; 


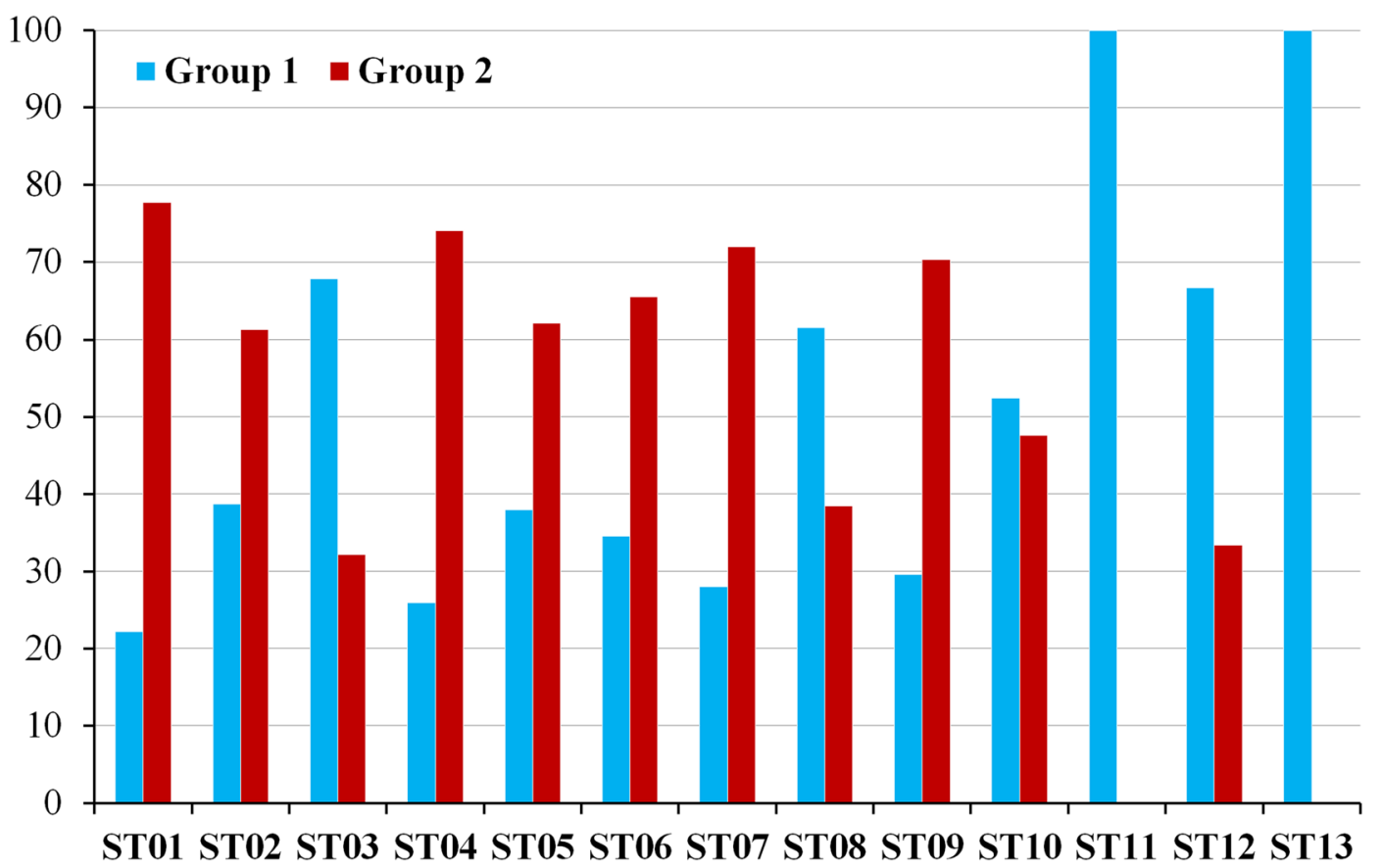

Fig. 3 Percentage of distribution of pubescent oak specimens in the two groups identified by fuzzy K-means clustering for each of the thirteen populations sampled.

Brullo et al. 1999b, 2001; Blasi et al. 2004; Brullo et al. 2009; Casavecchia et al. 2017). On the other hand, the group of 'lumper taxonomists' tend to reduce the number of white oaks occurring in the Italian peninsula to four species only.

In our opinion, the problem is partly conceptual and partly methodological. The wide morphological variability exists not only in the pubescent oaks group as a whole, but also within populations of the same putative pubescent oak species. The 'splitters' consider unlikely that such a wide variability could be displayed by a single species. On the other hand, there is evidence that when collections include a large number of populations and a large number of specimens per population, the variability tends to follow more or less continuous pattern in nearly all the diagnostic morphological characters. This gradual morphological pattern was clearly demonstrated in Di Pietro et al. (2016) in the Apulia region, who covered the entire bioclimatic and lithological variability of the study area and collected an adequate number of populations and specimens per population. In this study, no groups of morphological and molecular diversity and no combination of diagnostic characters were found to identify the putative species reported to dominate the study sites, such as $Q$. dalechampii, $Q$. pubescens and $Q$. virgiliana
(Biondi et al. 2004; Di Pietro and Misano 2009). Indeed, a more recent study using fractal analysis applied to the leaves of Calabrian deciduous oaks (Musarella et al. 2018) was also unable to distinguish different species inside the $Q$. pubescens group.

In the present research on the Calabrian and $\mathrm{Si}$ cilian oaks, we decided to further improve the sampling protocol by increasing the number of specimens per site and to include the loci classici of some of the species sampled. No consistent groups were found at the morphological level whereas, according to the published phytosociological studies, we should have found $Q$. amplifolia, $Q$. congesta, $Q$. dalechampii $Q$. leptobalana and $Q$. virgiliana. Taking the high frequency and cover values of these species in the original phytosociological tables into account, it would have been unlikely to avoid collecting a sample of one or more of these species given the randomized sampling protocol we adopted. The distribution of specimens into the two main clusters identified by cluster analyses was found to be rather random and unrelated to ecological or geographical characters. For example, specimens we collected from a putative thermoMediterranean and xerothermic $Q$. virgiliana- $Q$. amplifolia community on limestone were found to 
group together with specimens of a putative $Q$. congesta-Q. dalechampii community from the montane belt of the Etna Volcano where neither $Q$. virgiliana nor $Q$. amplifolia were reported. As a further example, we would have expected that specimens collected from the only two sites known to host Quercetum leptobalanae (cf. Brullo 1984; Brullo and Marcenò 1985; Gianguzzi and La Mantia 2004) would have grouped together. Instead, all the specimens from the site 'Piano Zucchi' (locus classicus of the Quercetum leptobalanae) clustered in Group 1 whereas two thirds of the specimens of Quercetum leptobalanae from 'Bosco Ficuzza' clustered in Group 2.

The morphological characters that were diagnostic for the two clusters deriving from fuzzy k-means analysis seem to suggest the existence of two morphotypes. One (Group 2) is characterized by greater dimensional characteristics of leaves (as regards the leaf lamina, petiole length, depth of the lobes) and bigger acorns, while the second (Group 1) has smaller and more compact leaves and smaller acorns. However, observing the box plots (Online Resource 5), the situation is much more complex and all the characters show a wide variation range. From a taxonomical point of view, the two morphotypes are difficult to match to any of the putative oak species that were the object of this study, neither in respect of their original descriptions nor of those proposed in analytical keys (Brullo et al. 1999a, b; Pignatti et al. 2017-2019). In fact, many of the morphological characters we found to discriminate between the two major clusters are dimensional characters. These are known to exhibit a wide range of variation depending on the site environmental conditions and on seasonal variations of the climate factors and may change from one year to another (cf. Škvorc et al. 2005; Bonito et al. 2011; Martiník et al. 2014). Theoretically, the use of many morphological characters in statistical analyses could have caused excessive background noise caused by characters that are non-diagnostic. This possibility is, however, largely refuted by the recent taxonomic literature, which tends to use the greatest number of available characters to discriminate at the interspecific and intraspecific levels. Moreover, it has been shown that if populations of other white oak species, such as $Q$. petraea and $Q$. frainetto, are included in statistical analysis together with populations of $Q$. pubescens s.l., the specimens belonging to the two former separate quite clearly from the undifferentiated bulk of specimens belonging to $Q$. pubescens s.l. (Viscosi and Fortini 2011; Fortini et al. 2015).

Aware of the difficulties in identifying and classifying white oaks, we also opted to perform our expert identification of the specimens using the analytical keys proposed in Pignatti et al. (2017-2019) and to compare results of our classification with cluster analyses and the PCA (Online resource 4a,h). We expected the identified species to correspond to some ecological factors (e.g. bioclimatic belt, type of substrate) or at least to the species reported in the published phytosociological tables. These expectations were largely unmet (Table 5). For example, only twelve specimens were ascribable with certainty to Quercus virgiliana whereas we would have expected the number to be not less than 100. A total of 39 specimens were attributable to Q. leptobalana but only fourteen specimens $(36 \%)$ came from the two sites of Quercetum leptobalanae (4 specimens in ST1 and 10 in ST11), while the remaining specimens were distributed in other collection sites. Such results would be new sites for $Q$. leptobalana in Sicily and first records of this taxon for continental Europe. In contrast, no specimens classifiable as Q. amplifolia were found even though, according to the phytosociological literature, this species should occur in at least $60 \%$ of the communities we sampled. Finally, we found specimens attributable to Q. pubescens (35) and Q. ichnusae (7) although the former species is considered to be absent in southern Italy and the latter endemic to Sardinia Island (Mossa et al. 1999).

It is possible that in southern Italy and Sicily the morphological variability among pubescent oaks is greater than in other countries, and this fact led botanists from the early nineteenth century (Pres1 1822, 1826; Tenore 1830, Tenore 1835-36; Gussone 1844; Borzì 1905, 1911; Lojacono-Pojero 1907, 1913-15) to the present days (Brullo et al. 1999a, b; Giardina et al. 2007; Pignatti et al. 20172019) to consider the local pubescent oak populations as a multi-species complex. In opposite, we suggest that this high morphological variability (if really higher than in similar other areas at all) may be explained by biogeographic history processes and hybridization. The Apennine Peninsula is universally considered one of the most important refuge sites for the thermophilous oak forest during the Quaternary cold periods (Follieri et al. 1989; Hewitt 1999; Allen et al. 2000; Petit et al. 2002). 
In particular, the southern Apennines and the major islands suffered only in a very moderate way the effects of the glaciations, compared with the central and northern Apennines (see Acquafredda and Palmentola 1986; Di Pietro et al. 2017), so extinction of genotypes and populations was minimized. As suggested by Nieto Feliner (2011), adverse periods of climatic oscillations may have given rise to a low spatial scale dynamism with species movement 'across a wide possibility of patches and altitudes with more source diversity at genotype and population level'. Southern Italy oak species had thus higher chance to be in close contact and possibly to produce hybrids than in more northern areas. At this point, the question raises which oaks are more likely to have hybridized. Our opinion is that the most likely hybrids are those between a pubescent oak (e.g. Quercus pubescens) and other white oaks today unquestionably recognized as valid species (Q. petraea, Q. robur and Q. frainetto). Indeed, Fortini et al. (2015) identified presence of genomes of $Q$. frainetto, $Q$. petraea and $Q$. pubescens (in variable quantities) in several oak specimens collected in mixed oak woods of southern Italy, showing intermediate morphological characters.

The results of the present research suggest that all the populations we collected can be assigned to a single species of pubescent oak characterized by high morphological variability and presumably a wide ecological amplitude, too. A name that would correspond perfectly to the identity of this morphologically and ecologically highly variable species is, in fact, Q. pubescens Willd. This statement, despite being in contradiction with the taxonomic and phytosociological literature concerning southern Italy cited above, is actually in accordance with what has already been published for the whole Southern Europe: it is impossible to trace reliable species boundaries within the complex of pubescent oaks (cf. Franjic et al. 2006; Enescu et al. 2013; Wellstein and Spada 2015; Di Pietro et al. 2016, 2020). More information useful for unravelling the taxonomic-nomenclatural tangle of oaks can be derived from comparative studies combining morphological and molecular analyses. For example, interesting results on the association between one genomic region and leaf traits were recently obtained in a study on two interfertile and partially sympatric red oak species of North America (Gailing et al. 2018). As regards the Italian white oaks, the preliminary results of the genetic analysis carried out on the same set of populations and specimens as used in this paper (Di Pietro et al. submitted) show significant concordance between molecular and morphological results in terms of an absence of genetic groups of variation. Similar comparative studies have already been published for other Italian areas (Fortini et al. 2015; Di Pietro et al. 2016, 2020) and have also suggested that occurrence of more than one species of pubescent oaks in those study areas was unlikely.

\section{Conclusions}

Sicily and southern Calabria form a very important phytogeographical district, which is located in the centre of the Mediterranean Basin and is notoriously populated by a high number of endemics, relict and rare species (Brullo et al. 2011; Sciandrello et al. 2015; Spampinato et al. 2018). As far as the genus Quercus is concerned, this area is known to host five pubescent oak species, four of which were typified there. These species, in addition to all being accepted in the latest edition of the Flora of Italy and partly in Flora Europaea and in other European National floras and checklists, were used as name-giving species in several phytosociological syntaxa and considered diagnostic for some Forest Habitats included in the 92/43/ EEC Directive (Biondi et al. 2009; European Commission 2013).

The morphological analysis of specimens from thirteen pubescent oak populations of Sicily and southern Calabria performed both without a priori identification and through expert identification based on the published analytical keys, led to results that were incompatible with each other and with published data on pubescent oak species occurring in the study area and their distributional and ecological ranges. It seems more probable that the morphological variability can be assigned to a single species that is characterized by a wide phenotypic and ecological amplitude. 
Acknowledgements Sincere thanks are given to the Editor-inChief Petr Koutecký and two anonymous reviewers who read, and commented on, the earlier versions of the manuscript. Thanks also to Jim Mc Manus and for the linguistic revision of some parts of the text.

Funding Open access funding provided by Università degli Studi di Roma La Sapienza within the CRUI-CARE Agreement.

Open Access This article is licensed under a Creative Commons Attribution 4.0 International License, which permits use, sharing, adaptation, distribution and reproduction in any medium or format, as long as you give appropriate credit to the original author(s) and the source, provide a link to the Creative Commons licence, and indicate if changes were made. The images or other third party material in this article are included in the article's Creative Commons licence, unless indicated otherwise in a credit line to the material. If material is not included in the article's Creative Commons licence and your intended use is not permitted by statutory regulation or exceeds the permitted use, you will need to obtain permission directly from the copyright holder. To view a copy of this licence, visit http://creativecommons.org/licenses/by/4.0/.

\section{References}

Acquafredda P, Palmentola G (1986) The Quaternary glacialism in the southern Italy. Lav Soc Ital Biogeogr 10:13-18

Addinsoft (2020) XLSTAT statistical and data analysis solution. Paris, France. https://www.xlstat.com

Allen JRM, Watts WA, Huntley B (2000) Weichselian palynostratigraphy, palaeovegetation and palaeoenvironment: the record from Lago Grande di Monticchio, southern Italy. Quatern Int 73-74:91-110

Amaral Franco J (1990) Quercus L. In Castroviejo S, Laínz M, López G, Montserrat P, Muñoz F, Paiva J, Villar L (eds) Flora Ibérica. II. Plantas Vasculares de la Península Ibérica e Islas Baleares. RJBM-CSIC, Madrid, pp. 16-36

Bakis Y, Babaç MT (2014) Morphological variability of acorns and its taxonomic significance in Quercus from Turkey. Bangladesh J Bot 43:293-299

Barina Z, Somogyi G, Pifkó D, Rakaj M (2018) Checklist of vascular plants of Albania. Phytotaxa 378:001-339

Bartolucci F, Peruzzi L, Galasso G, Albano A, Alessandrini A, Ardenghi NMG, Astuti G, Bacchetta G, Ballelli S, Banfi E, Barberis G, Bernardo L, Bouvet D, Bovio M, Cecchi L, Di Pietro R, Domina G, Fascetti S, Fenu G, Festi F, Foggi B, Gallo L, Gottschlich G, Gubellini L, Iamonico D, Iberite M, Jiménez-Mejías P, Lattanzi E, Marchetti D, Martinetto E, Ma- sin RR, Medagli P, Passalacqua NG, Peccenini S, Pennesi R, Pierini B, Poldini L, Prosser F, Raimondo FM, Roma-Marzio F, Rosati L, Santangelo A, Scoppola A, Scortegagna S, Selvaggi A, Selvi F, Soldano A, Stinca A, Wagensommer RP, Wilhalm T, Conti F (2018) An updated checklist of the vascular flora native to Italy. Pl Biosyst 152: 179-303
BGCI (2019) GlobalTreeSearch online database. Botanic Gardens Conservation International. Richmond, UK. Available at www.bgci.org/globaltree_search.php ()

Biondi E, Casavecchia S, Guerra V, Medagli P, Beccarisi L, Zuccarello V (2004) A contribution towards the knowledge of semideciduous and evergreen woods of Apulia (southeastern Italy). Fitosociologia 41:3-28

Biondi E, Blasi C, Burrascano S, Casavecchia S, Copiz R, Del Vico E, Galdenzi D, Gigante D, Lasen C, Spampinato G, Venanzoni R, Zivkovic L (2009) Manuale Italiano di Interpretazione degli habitat della Direttiva 92/43/CEE. SBI, MATTM, DPN. Available at http://vnr.unipg. it/habitat/index.jsp

Blasi C, Di Pietro R, Filesi L (2004) Syntaxonomical revision of Quercetalia pubescenti-petraeae in the Italian Peninsula. Fitosociologia 41:87-164

Bock B and Tison JM (2013) Révisions nomenclaturales et taxonomiques (note $\mathrm{n}^{\circ}$ 2). Bull. Soc. Bot. Centre-Ouest, 43: 213

Bonito A, Varone L, Gratani L (2011) Relationship between acorn size and seedling morphological and physiological traits of Quercus ilex L. from different climates. Photosynthetica 49: $75-86$

Borzì A (1905) Note critiche sulle Querci italiane. Boll Regionale Orto Bot Giardino Colon Palermo 4:40-49

Borzì A (1911) Le querce della Flora Italiana. Boll Regionale Orto Bot Giardino Colon Palermo 10:41-66

Brullo S. (1984) Contributo alla conoscenza della vegetazione delle Madonie (Sicilia settentrionale). Boll Accad Gioenia Sci Nat Catania 16:351-420

Brullo S, Marcenò C (1985) Contributo alla conoscenza della classe Quercetea ilicis in Sicilia. Not Fitosoc 19:183-229

Brullo S, Guarino R, Siracusa G (1999a) Revisione tassonomica delle querce caducifoglie della Sicilia. Webbia 54:1-72

Brullo S, Scelsi F, Siracusa G, Spampinato G (1999b) Considerazioni sintassonomiche e corologiche sui querceti caducifogli della Sicilia e della Calabria. Monti \& Boschi 1: 16-29

Brullo S, Scelsi F, Spampinato G (2001) La vegetazione dell'Aspromonte. Studio Fitosociologico. Laruffa Editore, Reggio Calabria

Brullo S, Gianguzzi L, La Mantia A, Siracusa G (2009) La classe Quercetea ilicis in Sicilia. Boll Accad Gioenia Sci Nat Catania 41:1-80

Brullo C, Minissale P, Sciandrello S, Spampinato G (2011) Evaluation of the endemic vascular flora of Hyblaean territory (SE Sicily-Italy). Acta Bot Gallica 158:617-631

Brundu G, Peruzzi P, Domina G, Bartolucci F, Galasso G, Peccenini S, Raimondo F, Albano A, Alessandrini A, Banfi E, Barberis G, Bernardo L, Bovio M, Brullo S, Brunu A, Camarda I, Carta L, Conti F, Croce A, Iamonico D, Iberite M, Iiriti G, Longo D, Marsili S, Medagli P, Mariotti MG, Pennesi R, Pistarino A, Salmeri C, Santangelo A, Scassellati E, Selvi F, Stinca A, Vacca G, Villani M, Wagensommer RP \& Passalacqua NG (2017) At the intersection of cultural and natural heritage: the distribution and conservation of the type localities of the Italian endemic vascular plants. Biological Conservation 214:109-118

Bruschi P, Vendramin GG, Bussotti F, Grossoni P (2000) Morphological and molecular differentation between Quercus petraea (Matt.) and Quercus pubescens Willd. 
(Fagaceae) in northern and central Italy. Ann Bot (Oxford) 85: 325-333

Burger WC (1975) The species concept in Quercus. Taxon 24:4550

Camus A (1936-54) Le Chénes: monographie du genere Quercus. Vol. I-III. Edit. P. Lechevalier, Paris

Casavecchia S., Biondi E., Pesaresi S., Galdenzi D., Bacchetta G., Gianguzzi L., Facioni L., Blasi C. (2017) The order Quercetalia virgilianae: a new proposal for the classification of semi-deciduous forests in the Mediterranean and subMediterranean area. Atti del $51^{\circ}$ Congresso della Società Italiana di Scienza della Vegetazione: Servizi Ecosistemici e Scienza della Vegetazione. Bologna, 20-21 aprile 2017

Cavender-Bares J (2019) Diversification, adaptation, and community assembly of the American oaks (Quercus), a model clade for integrating ecology and evolution. New Phytol 221:669692

Crăciunescu I, Vornam B, Leinemann L, Finkeldey R, Şofletea N, Curtu AL (2015) High genetic differentiation among European white oak species (Quercus spp.) at a dehydrin gene. Notul Bot Horti Agrobot Cluj-Napoca 43:582-588

Crowl AA, Manos PS, McVay JD, Lemmon AR, Lemmon EM, Hipp AL (2019) Uncovering the genomic signature of ancient introgression between white oak lineages (Quercus). New Phytol 226:1158-1170

Curtu AL, Gailing O, Finkeldey R (2007a) Evidence for hybridization and introgression within a species-rich oak (Quercus spp.) community. BMC Evol Biol 7:218-233

Curtu AL, Gailing O, Leinemann L, Finkeldey R (2007b) Genetic variation and differentiation within a natural community of five oak species (Quercus spp.). Pl Biol 9:116-126

Curtu AL, Moldovan IC, Enescu CM, Craciunesc I, Sofletea N (2011) Genetic differentiation between Quercus frainetto Ten and Q. pubescens Willd. in Romania. Notul Bot Horti Agrobot Cluj-Napoca Inst 39:275-282

Curtu AL, Crăciunescu I, Enescu CM, Vidalis A, Sofletea N (2015) Fine-scale spatial genetic structure in a multi-oakspecies (Quercus spp.) forest. iForest 8:324-332

Denk T, Grimm GW (2010) The oaks of western Eurasia: traditional classifications and evidence from two nuclear markers. Taxon 59:351-366

Denk T, Grimm GW, Manos PS, Deng M, Hipp AL (2017) An updated infrageneric classification of the oaks: review of previous taxonomic schemes and synthesis of evolutionary patterns. In Gil-Pelegrín E, Peguero-Pina JJ, Sancho-Knapik D (eds) Oaks physiological ecology. Exploring the Functional Diversity of Genus Quercus L. Springer, Cham, pp. $13-38$

Di Pietro R, Misano G (2009) Analisi fitosociologica e considerazioni sintassonomiche sulla vegetazione forestale delle Gravine occidentali dell'Arco Ionico (Murge pugliesi e lucane, Italia meridionale). Inform Bot Ital 41:215-246

Di Pietro R, Viscosi V, Peruzzi L, Fortini P (2012) A review of the application of the name Quercus dalechampii. Taxon 61: 1311-1316

Di Pietro R, Di Marzio P, Medagli P, Misano G, Silletti GN, Wagensommer RP, Fortini P (2016) Evidence from multivariate morphometric study of the Quercus pubescens complex in southeast Italy. Bot Serbica 40:83-10

Di Pietro R, Terzi M, Fortini P (2017) A revision of the highaltitude acidophilous and chionophilous grasslands of the
Apennines (Peninsular Italy), a long-lasting intricate syntaxonomic issue. Phytocoenologia 47:261-304

Di Pietro R, Di Marzio P, Antonecchia G, Conte AL, Fortini P (2020) Preliminary characterization of the Quercus pubescens complex in southern Italy using molecular markers. Acta Bot Croat 79:15-25

Dimopoulos P, Raus T, Bergmeier E, Constantinidis T, Iatrou G, Kokkini S, Strid A, Tzanoudakis D (2016) Vascular plants of Greece: an annotated checklist. Willdenowia 46:301-347

Eaton DAR, Hipp AL, Gonzalez-Rodriguez A, Cavender-Bares J (2015) Historical introgression among the American live oaks and the comparative nature of tests for introgression. Evolution 69:2587-2601

Enescu CM, Curtu AL, Șofletea N (2013) Is Quercus virgiliana a distinct morphological and genetic entity among European white oaks? Turk J Agric Forest 37:632-641

Euro+Med (2006-2014) Euro+Med Plant Base - the information resource for Euro-Mediterranean plant diversity. Avaliable at http://ww2.bgbm.org/EuroPlusMed (Accessed 10 July 2017)

European Commission (2013) Interpretation manual of European Union habitats. - EUR 28. Available at https://ec.europa. $\mathrm{eu} / \mathrm{environment/nature/legislation/habitatsdirective/docs/Int}$ Manual_EU28.pdf

Follieri M, Magri D, Sadori L (1989) Pollen stratigraphical synthesis from Valle di Castiglione (Roma). Quatern Int 3:8184

Fortini P, Viscosi V, Maiuro L, Fineschi S, Vendramin GG (2009) Comparative leaf surface morphology and molecular data of five oaks of subgenus Quercus Oerst. (Fagaceae). Pl Biosyst 143:543-554

Fortini P, Di Marzio P, Di Pietro R (2015) Differentiation and hybridization of Quercus frainetto, $Q$. petraea, and $Q$. pubescens (Fagaceae): insights from macromorphological leaf traits and molecular data. Pl Syst Evol 301:375-385

Franjic J, Liber Z, Skvorc Z, Idzojtic M, Sostaric R, Stancic Z (2006) Morphological and molecular differentiation of the Croatian populations of Quercus pubescens Willd. (Fagaceae). Acta Soc Bot Poloniae 75:123-130

Gailing O, Kostick S, Caré O, Khodwekar S (2018) Leaf morphological and genetic variation between Quercus rubra and Quercus ellipsoidalis: comparison of sympatric and parapatric populations. Ann Forest Res 61:81-94

Gerber S, Chadoeuf J, Gugerli F, Lascoux M, Buiteveld J, Cottrell J, Dounavi A, Fineschi S, Forrest LL, Fogelqvist J, Goicoechea PG, Jensen JS, Salvini D, Vendramin GG, Kremer A (2014) High rates of gene flow by pollen and seed in oak populations across Europe. PLoS ONE 9:e85130

Gianguzzi L, La Mantia A (2004) Le serie di vegetazione della Riserva Naturale Orientata "Bosco Ficuzza, Rocca Busambra, Bosco del Cappelliere e Gorgo del Drago" con allegata carta della vegetazione (scala 1:20 000). Naturalista Sicil 28:205-242

Gianguzzi L, Papini F, Cusimano D (2016) Phytosociological survey vegetation map of Sicily (Mediterranean region). $J$ Maps 12:845-851

Giardina G, Raimondo FM, Spadaro V (2007) A catalogue of plants growing in Sicily. Bocconea 20:5-582

Govaerts R, Frodin DG (1998) World checklist and bibliography of Fagales. Royal Botanic Gardens, Kew 
Guarino R., Bazan G., Paura B. (2015) Downy-oak woods of Italy: phytogeographical remarks on a controversial taxonomic and ecologic issue. In Box E, Fujiwara K (eds) Warm-temperate deciduous forest around the Northern Hemisphere. Geobotany studies (basics, methods and case studies). Springer

Gussone J (1844) Florae siculae synopsis. Vol. 2 Tremater, Neapoli, pp 602-608

Hammer Ø, Harper DAT, Ryan PD (2001) PAST: Paleontological statistics software package for education and data analysis. Palaeontol Electron 4:1-9

Hardin JW (1975) Hybridization and introgression in Quercus alba. J Arnold Arbor 56:336-363

Hewitt GH (1999) Post-glacial re-colonization of European biota. Biol J Linn Soc 68:87-112

Hipp, AL (2015) Should hybridization make us skeptical of the oak phylogeny? Int Oaks 26:9-17

Hipp AL, Manos P, McVay JD, Cavender-Bares J, GonzálezRodriguez A, Romero-Severson J, Hahn M, Brown BH, Budaitis B, Deng M, Grimm G, Fitzek E, Cronn R, Jennings TL, Avishai M, Simeone MC (2015) A phylogeny of the world's oaks. Botany 2015, Edmonton

Hipp AL, Manos PS, Gonzalez-Rodriguez A, Hahn M, Kaproth M, McVay JD, Avalos SV, Cavender-Bares J (2018) Sympatric parallel diversification of major oak clades in the Americas and the origins of Mexican species diversity. New Phytol 217:439-452

Hipp AL, Manos PS, Hahn M, Avishai M, Bodénès C, CavenderBares J, Crowl AA, Deng M, Denk T, Fitz-Gibbon S, Gailing O, González-Elizondo MS, González-Rodríguez A, Grimm GW, Jiang X-L, Kremer A, Lesur I, McVay JD, Plomion C, Rodríguez-Correa H, Schulze E-D, Simeone MC, Sork VL, Valencia-Avalos S (2019) Genomic landscape of the global oak phylogeny. New Phytol 226:1198-1212

Hubert F, Grimm GW, Jousselin E, Berry V, Franc A, Kremer A (2014) Multiple nuclear genes stabilize the phylogenetic backbone of the genus Quercus. Syst Biodivers 12:405-423

JASP Team (2020) JASP (Version 0.13) [Computer software]

Jedináková-Schmidtová J, Paule L, Magic D, Gomory D (2004) Morphological and genetic differentiation among the Central European White Oaks. Forest Genet 11:263-271

Kissling P (1980) Clef de détermination des chênes médioeuropéens (Quercus L.) Ber Schweiz Bot Ges 90:2

Kremer A, Hipp AL (2019) Oaks: an evolutionary success story. New Phytol 226:987-1011

Kremer A, Dupouey JL, Deans JD, Cottrell J, Csaikl U, Finkeldey R, Espinel S, Jensen J, Kleinschmit J, Van Dam B, Ducousso A, Forrest I, Lopez de Heredia U, Lowe AJ, Tutkova M, Munro RC, Steinhoff S, Badeau V (2002) Leaf morphological differentiation between Quercus robur and Quercus petraea is stable across western European mixed oak stands. Ann Forest Sci 59:777-787

Kremer A, Abbott A, Carlson J, Manos PS, Plomion C, Sisco P, Staton M, Ueno S, Vendramin G (2012) Genomics of Fagaceae. Tree Genet Genomes 8:583-610

Kučera P (2018) New name for Central Europaean oak formerly labelled as Quercus dalechampii. Biologia 73:313-317

Leroy T, Louvet JM, Lalanne C, Le Provost G, Labadie K, Aury JM, Delzon S, Plomion C, Kremer A (2019a) Adaptive introgression as a driver of local adaptation to climate in European white oaks. New Phytol 226:1171-1182
Leroy T, Rougemont Q. Dupouey JL, Bodenes C, Lalanne C, Belser C, Labadie K, Le Provost G, Aury JM, Kremer A et al. (2019b) Massive postglacial gene flow between European white oaks uncovered genes underlying species barriers. New Phytol 226:1183-1197

Lind-Riehl JF, Sullivan AR, Gailing O (2014) Evidence for selection on a CONSTANS-like gene between two red oak species. Ann Bot (Oxford) 113:967-975

Lojacono-Pojero M (1907) Flora Sicula o descrizione delle piante spontanee o indigenate in Sicilia, Vol. 2, Tipografia Virzì, Palermo, pp 364-389

Lojacono-Pojero M (1913-15) Di nuovo sulle querce di Sicilia dopo la comparsa dello studio del Prof. A. Borzì: "Le Querce della Flora Italiana”. Malpighia 26:519-526; 27:77-100

Magri D, Fineschi S, Bellarosa R, Buonamici A, Sebastiani F, Schirone B, Vendramin GG (2007) The distribution of Quercus suber chloroplast haplotypes matches the palaeogeographical history of the western Mediterranean. Molec Ecol 16:5259-5266

Manos PS, Cannon CH, Oh SH (2008) Phylogenetic relationships and taxonomic status of the paleoendemic Fagaceae of western North America: recognition of a new genus, Notholithocarpus. Madrono 55:181-191

Martiník A, Dobrovolný L, Palátová E (2014) Tree growing space and acorn production of Quercus robur. Dendrobiology 71: 101-108

McDonald JH (2009) Handbook of biological statistics, vol. 2, pp. 6-59. Baltimore, MD: sparky house publishing

Médail F, Diadema K (2009) Glacial refugia influence plant diversity patterns in the Mediterranean Basin. $J$ Biogeogr 36:1333-1345

Mossa L, Bacchetta G, Brullo S (1999) Quercus ichnusae (Fagaceae), a new species from Sardinia. Israel J Pl Sci 47: 199-207

Musarella CM, Cano-Ortiz A, Pinar Fuentes JC, Navas-Urena J, Pinto Gomes CJ, Quinto-Canas R, Cano E, Spampinato G (2018) Similarity analysis between species of the genus Quercus L. (Fagaceae) in southern Italy based on the fractal dimension. PhytoKeys 113:79-95

Nieto Feliner G (2011) Southern European glacial refugia: a tale of tales. Taxon 60:365-372

Nikolić T (2020) Flora Croatica database. Faculty of Science, University of Zagreb. Available at http://hirc.botanic.hr/fcd

Oh S-H, Manos PS (2008) Molecular phylogenetics and cupule evolution in Fagaceae as inferred from nuclear CRABS CLAW sequences. Taxon 57:434-451

Olalde M, Herran A, Espinel S, Goicoechea PG (2002) White oaks phylogeography in the Iberian Peninsula. Forest Ecol Managem 156:89-102

Oney-Birol S, Fitz-Gibbon S, Chen JM, Gugger PF, Sork VL (2018) Assessment of shared alleles in drought-associated candidate genes among southern California white oak species (Quercus sect. Quercus). BMC Genet 19:88

Panahi P, Jamzad Z, Pourmajidian M, Fallah A, Pourhashemi M, Sohrabi H (2012) Taxonomic revision of the Quercus brantii complex (Fagaceae) in Iran with emphasis on leaf and pollen micromorphology. Acta Bot Hung 54:355-375

Pasta S, de Rigo D, Caudullo G (2016) Quercus pubescens in Europe: distribution, habitat, usage and threats. In SanMiguelAyanz J, de Rigo D, Caudullo G, Houston Durrant 
T, Mauri A (eds) European atlas of forest tree species. Publ. Off. EU, Luxembourg, e019e5c+

Peruzzi L, Galasso G, Domina G, Bartolucci F, Santangelo A, Alessandrini A, Astuti G, D’Antraccoli M, Roma-Marzio F, Ardenghi NMG, Barberis G, Conti F, Bernardo L, Peccenini S, Stinca A, Wagensommer RP, Bonari G, Iamonico D, Iberite M, Viciani D, Del Guacchio E, Gusso del Galdo G, Lastrucci L, Villani M, Brunu A, Magrini S, Pistarino A, Brullo S, Salmeri C, Brundu G, Clementi M, Carli E, Vacca G, Marcucci R, Banfi E, Longo D, Di Pietro R \& Passalacqua NG (2019) An inventory of the names of native, non-endemic vascular plants described from Italy, their loci classici and types. Phytotaxa 410: 1-215

Petit RJ, Brewer S, Bordács S, Burg K, Cheddadi R, Coart, E, Cottrell J, Csaikl UM, Van Dam B, Deans JD, Espinel S, Fineschi S, Finkeldey R, Glaz I, Goicoechea PG, Jensen JS, König AO, Lowe AJ, Madsen SF, Mátyás G, Munro RC, Popescu F, Slade D, Tabbenerg H, de Vriesh SGM, Ziegenhagen B, de Beaulieu J-L, Kremer A (2002) Identification of refugia and post-glacial colonisation routes of European white oaks based on chloroplast DNA and fossil pollen evidence. Forest Ecol Managem 156:49-74

Petit RJ, Bodénès C, Ducousso A, Roussel G, Kremer A (2006) Hybridization as a mechanism of invasion in oaks. New Phytol 161:151-164

Pignatti S (1982) Flora d'Italia, Vol. 1. Edagricole, Bologna, pp $113-120$

Pignatti S, Guarino R, La Rosa M (2017-2019) Flora d'Italia, $2^{\circ}$ Edizione. Edagricole - Edizioni agricole di New Business Media, Vol. 4, pp 112-116, 605-606; 2, pp. 686-697

Presl CB (1822) Quercus. In Presl JS, Presl CB (eds) Deliciae pragensis historiam naturalem spectantes. Calve, Pragae, pp. $1-32$

Presl CB (1826) Flora Sicula, exhibens plantas vasculosas in Sicilia aut sponte aut crescents aut frequentissime cultas, secundum systema natural digestas, Sumptibus A. Borrosch, Pragae

Rasband WS (1997-2007) Image J. US National Institutes of Health, Bethesda, Maryland, USA. Avaliable at http://rsb. info.nih.gov/ij

Rohlena J (1942) Conspectus florae montenegrinae. Preslia 2021:1-506

Scareli-Santos C, Herrera-Arroyo ML, Sánchez-Mondragon ML, González-Rodríguez A, Bacon J, Oyama K (2007) Comparative analysis of micromorphological characters in two distantly related Mexican oaks, Quercus conzattii and Q. eduardii (Fagaceae), and their hybrids. Brittonia 59:37

Scareli-Santos C, Sánchez-Mondragón ML, González-Rodríguez A, Oyama K (2013) Foliar micromorphology of mexican oaks (Quercus: Fagaceae). Acta Bot Mex 104:31-52

Schwarz O (1993) Quercus L. pp 72-76. In Tutin TG., Burges NA, Chater AO, Edmondson JR, Heywood VH, Moore DM,
Valentine DH, Walters SM, Webb DA (eds) Flora Europaea, Vol. 1, 2nd Edition, Cambridge University Press.

Sciandrello S, Guarino R, Minissale P, Spampinato G (2015) The endemic vascular flora of Peloritani Mountains (NE Sicily): plant functional traits and phytogeographical relationships in the most isolated and fragmentary micro-plate of the Alpine orogeny. Pl Biosyst 149:838-854

Škvorc Ž, Franjić J, Idžojtić M (2005) Population structure of Quercus pubescens Willd. (Fagaceae) in Croatia according to morphology of leaves. Acta Bot Hung 47:193-206

Spampinato G, Musarella CM, Cano-Ortiz A, Signorino G (2018) Habitat, occurrence and conservation status of the SaharoMacaronesian and Southern-Mediterranean element Fagonia cretica L. (Zygophyllaceae) in Italy. J Arid Land 10:140-151

Stephan J, Teeny P (2017) Revealing the taxonomy of an endemic oak of Lebanon. Pl Sociol 54 Suppl. 1:97-100

Stevanović V (ed) (2012) Flora Srbije 2.Srpska akademija nauka i umetnosti. Beograd (in Serbian)

Tenore M (1830) Semina anno 1830 collecta, quae in Horto Botanico Neapolitano pro mutua commutatione offeruntur. Tipografia Fibreni, Neapoli

Tenore M (1835-1836) Flora Napolitana, Stampa Reale, 5, pp. 260-261

Trehane P (2007) The oak names checklist. Available at http://www.oaknames.org (Accessed 31 December 2019)

Turland NJ, Wiersema JH, Barrie FR, Greuter W, Hawksworth DL, Herendeen PS, Knapp S, Kusber W-H, Li D-Z, Marhold K, May TW, McNeill J, Monro AM, Prado J, Price MJ, Smith GF (eds) (2018) International code of nomenclature for algae, fungi, and plants (Shenzhen Code), adopted by the Nineteenth International Botanical Congress Shenzhen, China, July 2017. Regnum Vegetabile 159. Glashütten: Koeltz Botanical Books

Van Valen L (1976) Ecological species, multispecies, and oaks. Taxon 25:233-239

Viscosi V, Fortini P (2011) Leaf shape variation and differentiation in three sympatric white oak species revealed by elliptic Fourier analysis. Nordic J Bot 29:632-640

Raab-Straube E von, Raus Th (2013) Euro+ Med-Checklist Notulae, 1. Willdenowia 43:151-164

WCSP (2019) World checklist of selected plant families. Facilitated by the Royal Botanic Gardens, Kew. Available at http://wcsp.science.kew.org ()

Wellstein C, Spada F (2015) The status of Quercus pubescens Willd. in Europe. In Box EO, Fujiwara K (eds) Warm-temperate deciduous forests around the Northern Hemisphere. Springer, Cham, pp. 153-163

Publisher's note Springer Nature remains neutral with regard to jurisdictional claims in published maps and institutional affiliations. 